\title{
Historic Architecture \& THE ANCIENT ART Of PlanNing: The ERA ForgotTEN
}

\author{
Ar. Kaninika Dey Sarkar \\ Mba-Real Estate \& Urban Infrastructure, Rics School Of Built Environment, Amity \\ University Uttar Pradesh
}

\begin{abstract}
This paper is a literature study that discusses the magic of ancient Architecture, planning and construction techniques of the World. It is a brief study that describes and explains various elements of how architecture, planning and construction evolved in various corners of the world. Architecture is the art form which merges Art with Science. It unites aesthetics, safety, structure, dimensions and emotions in a solid built state. Architecture, planning and construction of shelters, temples and cities had a very primitive origin dating to the beginning of mankind. As mankind evolved so did Architecture and planning. This paper follows the traces of historic changes in trends, cultures, traditions, styles and regions through time. The various stages of evolutions are described below along with the visionary changes in Architecture, planning and construction over time. This paper is an effort to concise the evolution of architecture, planning and construction from the very beginning to a few pages.
\end{abstract}

\section{KEYWORDS}

Architecture, Planning, Construction, Ancient, historic, Evolution, planning, architecture, pre-historic, Beginning, India, Vastu Shastra, Vedic planning, Greek architecture, Roman architecture, Egyptian Architecture, Indus Valley civilisation

\section{INTRODUCTION}

Architecture began with the beginning of mankind. In the beginning Man had very basic needs; hence the built environment or the architecture style was minimalistic and basic. Man was only concerned with safety from wild beasts and enemies and shield against weather. The history of Architecture is classified as eras outlining the time period of man's existence. The first stage or era of architecture is the Pre-historic period, the era before history began to be documented. This era spanned the time period of $10,000-1500 \mathrm{BC}$.

\section{THE BEGINNING}

Since the beginning man had very basic requirements for livelihood. Architecture was related to two types of structures; shelters and worship or burial place. Shelters were huts built out of readily available local material. The Neanderthals built dwellings in a savage form; rock caves complimenting their hunter life style. Next was the "Barbarian" stage, where man started growing crops and reared cattle and started settling down. This was the time when Man started building houses, drainage, canals and defensive works. There are a very few surviving evidence of prehistoric architecture in today's date. Few megaliths known as "dolmens" have survived the tides of time and are found in Britain. It dates back to $2^{\text {nd }}$ or $3^{\text {rd }}$ millennium B.C. and were built tile the Saxon era. Stone Henge found in Salisbury is a very famous example of the pre historic architecture.

DOI:10.5121/civej.2016.3103 


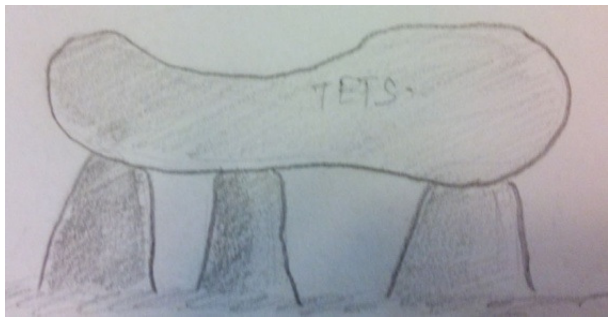

Figure 1: Dolmens

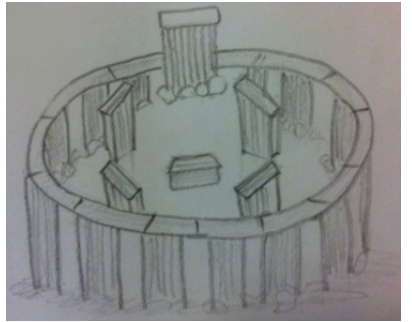

Figure 2: Stone Henge

\section{THE HISTORY}

Architecture as we know it today rightfully began in 3000BC in Egypt. Followed by the evolution of built world in Egypt, the Assyrians and Babylonians developed their own style of architecture depending on their requirements, materials and character. Soon, the Greeks and Romans followed suit.

India witnessed an extreme diversity in architecture, planning and construction. There was a great rise in Buddhist architecture, Jain architecture and finally Hindu architecture which developed in 600AD and has evolved till the present day. The word also witnessed the rise of Muslim architecture with spread of Muslim dynasties.

On the Western front, with the spread of Christianity, the Christian style took over followed by the Byzantine style. On the other side, there was a fast spread of Romanesque style of architecture followed by Gothic architecture. Next was the Renaissance style. When the industrial revolution took place in the $19^{\text {th }}$ century, population increased and so did the needs and requirements of the people. This paved the way for Modern architecture and thus began the fast progression of forgetting the History.

\section{EGYPTIAN ARCHITECTURE}

The Egyptians were consumed with the idea of life after death. Hence, the era is haracterized by pyramids, sphinxes and mastabas and tombs. The design and construction of this era is distinguished by close columns and massive walls. The Egyptian architecture gave rise to the style known as "Trabeated structure" style which is a beam and column structure. The Egyptians used locally available materials for construction of their structures. The abundant availability of rich clay from the Nile delta was used to make sun-dried bricks. It was mixed with reeds, palm leaves etc to make the bricks strong. Lime stone was copiously used especially for pyramids. Turra and Mokattam hills were the prime sandstone was spots for quarrying lime stone. Sandstone was used for building beautiful temples and sacred sarcophagus. For columns and architraves, red or grey sandstones brought from Aswan were used. [1]

The pharaohs consist of 30 dynasties and these dynasties developed and pushed Egyptian architecture forward. As time went on the style also evolved. Each dynasty had something new to offer. The first dynasty king, Pharaoh Menes united Upper and Lower Egypt. The capital city of Memphis on the west bank of river Nile was founded by Pharaoh Menes. During the rule of first to tenth dynasties, the Egyptian art progressed a lot. Historic events and religious rituals were represented by pictorial representation. There was tremendous development in art of writing and hieroglyphic system. Mastabas and royal pyramids were built during this time. Important example is that of Great pyramids of Pharaohs Cheops, Mykerinos at Giza and Chepren. Sphinx of king Chepren at Giza was also built during this period. [1] 
During the time period between $2130 \mathrm{BC}-1580 \mathrm{BC}$, that is the period of reign of dynasties 11 and 17 , the Pharaohs or the kings shifted their capital to Thebes. The pyramids built during this era were in crude bricks for interiors and stone masonry for outer surface. This epoch saw the development of many front open tombs at Beni Hasan. Great temple of Amon at Karnak and Obelisk at Heliopolis were some important examples of the architecture of the era. Akhenaten (1364BC-1347BC) developed the city of Tell-el-Amarna and shifted his capital here.

The houses built of unbaked bricks have long perished but the tombs, temples and pyramids which were built of stone are still in existence because of their incredible durability and planning which survived era after era and nature's wrath over the several millennia, a shining example of the forgotten period of architecture when even in the absence of modern technologies, Man created wonders that cannot be fathomed today even with the present science and technology. [2]

\section{WEST ASIATIC ARCHITECTURE}

The civilization spread along the rivers Tigris and Euphrates which was extremely fertile. Religion was the pre-dominant element of the civilization. Ziggurat, the wholly mountains with shrines on top were the places for worship. Each city had atleast one Ziggurat.

\subsection{Sumerian Architecture}

City of Ur was the finest example of city planning of the era. The Mesopotamian king, UrNammu erected the great Ziggurat of Ur-Nammu here. The whole mass was solid and has sunbaked bricks at core and burnt bricks on the outer walls, the other famous ziggurat of the time; Ziggurat of Choga Zanbil. [1]

\subsection{Babylonian Architecture}

The city of Babylon or the gateway of god was founded by a nomadic tribe from Syrian Desert. The city employed simple defensive techniques in their planning like a moat running around the city and huge rampart walls and massive gateways which were soon employed by most kingdoms around the world. Ishtar gates were the gates dedicated to god Ishtar. The Hanging Gardens of Babylon were built by king Nebuchadnezzar to please his wife who was home sick for woodlands. [1]

\subsection{Assyrian Architecture}

Ashur, the city named after god was founded by the Assyrians as their capital. This time around the civilization evolved and changed in terms of worship places; there were many temples without the Ziggurats. There were temples with ziggurats as well and the double Ziggurat temple of Anu and Adad was most famous. The city of Khorsabad founded by Sargon II was even more developed with several office buildings as people became more civilized and evolved. [1]

\section{GREEK ARCHITECTURE}

Greece had profusion of locally available building materials. Marble was the unrivalled material found in abundance in Athens. The Greeks designed and built buildings according to their interests (outdoor life) like theatre, Agora, administrative buildings etc. Their love for beautiful variety gave rise to different columns; Doric, Ionic and Corinthian columns. Greek architecture was divided into 2 period; the Hellenic and Hellenistic period. 
The Hellenic period was the beginning of the Greek architecture. Greek architecture is characterized by the trabeated structures of the time. It is said to have evolved from wooden hut of upright posts and supporting beams and sloping rafters. Marble was used for finer works and sculptures and make beautiful façades. The walls were built of coursed rubble to fine Ashlar masonry and had marble cladding. Marble stucco was used to beautify the outer stone walls. Other features of Greek architecture were the colonnades, lack of windows, sloping roofs covered with terra cotta or marble tiles and the pediment. Outside of buildings were designed with colonnades. The tympana in the pediment were beautifully decorated with floral sculptures. In the Hellenistic period, public buildings began to appear, citizens developed civic sense and town planning was introduced and developed. Another important development in the Hellenistic period was the use of arches over the few windows. [2]

\section{ROMAN ARCHITECTURE}

The Romans occupied the whole part of Italy from the Etruscans in $300 \mathrm{BC}$. The original capital of Roma Empire near Tiber has seven sills protecting it. The materials used for buildings originated in Etruria. The Romans used a variety of materials- iron from Elba Island, copper from neighbouring islands, Stone and Timber. Unlike the Greeks, Romans leaned more towards natural, renewable building materials and sustainable architecture. Sustainable and earth architecture which began with the Romans have yet again taken precedence in modern architecture over the monotonous glass and steel buildings. In and around Rome there were plenty of Tufa stone, a stone of volcanic eruption from the Mt. Albano, had Limestone from Tivoli, pozzolana- volcanic earth readily available near Mt. Vesuvius and most importantly Lime concrete which was started in roman period. [2]

Roman architecture was characterized by the trabeated style of Greek architecture combined with the arches and vaults of Etruscan architecture. Unlike the Greeks, Romans built buildings in accordance with their power, i.e. they built buildings of several storeys. Coffers or recesses were often used to lighten the concrete vaults. On the outside, lime plaster was used and vault and marble stucco within. To the three Greek orders or columns, the Roman added the Composite and Tuscan order. They were used frequently for decoration or structural purposes. The orders were placed on pedestal to give height and were often super imposed. The orders added to the grandeur of Roman architecture. The beautiful majestic structures took a lot of labour and pain and time to be completed. The buildings prove the saying "Rome was not built in a day". Romans employed Greek artists for the ornamental work. [1]

\section{ARCHITECTURE OF INDIAN SUB-CONTINENT}

India or Bharat is strategically placed in Asia bound by Himalayas in the north which kept India apart from the rest of Asia; it is surrounded by sea on all its 3 sides by the Bay of Bengal, Arabian Sea and Indian Ocean thus classifying it as the "Indian Sub Continent".

Mohenjo-Daro(Hill of the Dead) and Harappa civilization(now in Pakistan) on the banks of river Indus and Ravi form the Indus Valley Civilization-one of the oldest planned civilizations dates back to 4000-3000BC. These cities are the finest and earliest examples of advanced system of town planning that rivals the town planning system of present day. [1] 


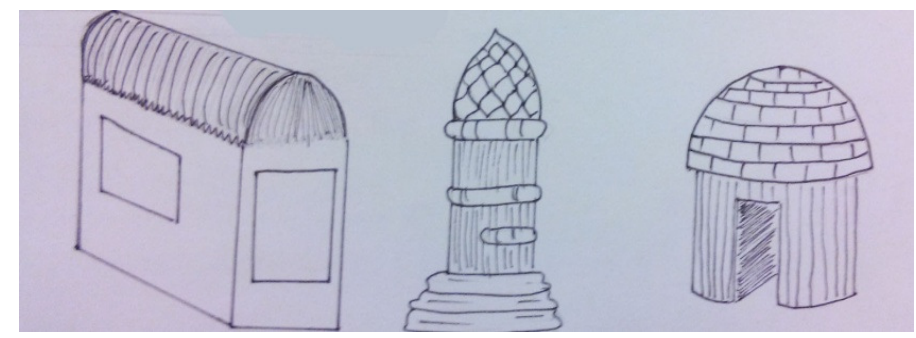

Figure 3: Shelters of Indus Valley Civilization

The core of architecture of Indian sub continent is deeply rooted in the diverse culture, history and various religions of the people. It progressed with the progressing time and incorporated the diverse elements of influences and invasions that came as a result of India' Global interest and significance in the world around over millennia.

\subsection{Vedic Architecture}

After the collapse of Indus valley civilization due to natural disasters and Aryan Invasion (1500BC-1000BC), the Vedic culture with Vedic style of architecture came into existence. These settlers were highly knowledgeable in the science of city planning. They founded many cities along the banks of rivers, Delhi being the most important of them all and was used as the Capital of all big dynasties including Prithvi Raj Chauhan to all Mughal Dynasty to British east India Company and now the capital of independent India. [3]Vedic principles of planning use the 4 Vedas; Rig Veda, Sam Veda, Atharva Veda and Yajur Veda. Vastu Shastra, Priccha, Manasollasa, Prasadamandana, Shilparatnam etc are treatise on architecture and planning based on Vedic hymns.

\subsubsection{Cities and Functions}

Nagara is a traditional city where the sacred and secular mingle. The Temples forms the link between the cosmic and human. The cities were laid according to various elements of Vedas:

- $\quad$ Sthapatya Veda - city layout

- $\quad$ Smriti Shastra - street layout on macro and micro level

- Vastu Shastra - building planning and design, site selection, service layout, landscaping and building orientation

- $\quad$ Arthashastra - environmental management

- Vastu Purusha mandala

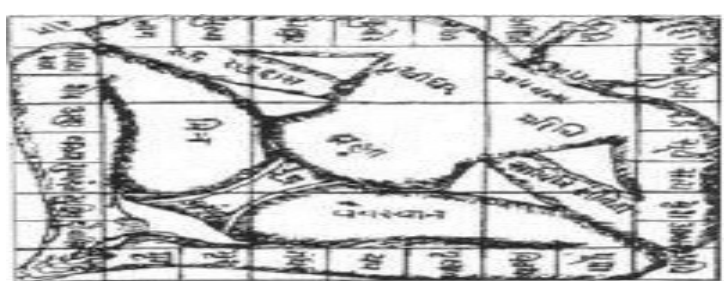

Figure 4: Vastu Purusha Mandala

\section{Vastu Shastra endorses 5 town shapes:}

- $\quad$ Chandura - square

- $\quad$ Agatara - rectangle

- Vritta - circle

- $\quad$ Kritta vritta - elliptical

- $\quad$ Gola vritta - full circle 


\subsection{Post Maha Jahanapadas period (600BC-200AD)}

This is the period of the rise of Buddhist architecture. The Mauryan Empire (c. 321-185 BC) developed the Fortified cities with stūpas, viharas, and temples. Wooden architecture and rock cut architecture became popular. Temples were built on elliptical, circular, quadrilateral, or apsidal plans using brick and timber. The gateway arches called the Torana, reached East Asia with the spread of Buddhism. Buddhist architecture unified with Roman architecture and Hellenestic architecture to give rise to unique blends-such as the GrecoBuddhist school. The greatest example of stupas is the great Sanchi Stupa built by Emperor Ashoka of the Mauryan Dynasty. [4]

\subsection{Early Common Era (200AD-1200AD)}

This era saw the rise of richly decorated temples constructed in Central India. Grandeur of construction, beautiful sculptures, delicate carvings, high domes, gopuras and extensive courtyards were the features of temple architecture in India. Examples; Lingaraj Temple at Bhubaneshwar, Sun Temple at Konark, Brihadeswarar Temple at Thanjavur. Various trade routes contributed in bringing Indian architecture to South East Asia.

\subsection{Late Middle Ages (1100AD-1526AD)}

The Late middle ages saw the evolution of Vijayanagara Architecture in 1336-1565AD in South India. The architecture and planning style is an amalgamation of Pandya, Hoysala, Chola and Chalukya kingdoms which developed in earlier centuries, characterised by simple and serene art. Examples of Hoysala architecture are; Chennakesava temple in Belur, Hoysaleswara temple at Halebidu and Kesava temple at Somanathapur. Hoysala architecture was influenced by IndoAryan style and South Indian style to larger extent. Today around 100 of these temples survive.

\subsection{Mughal Architecture (1526AD-1857AD)}

Persian architecture has strong influence on Mughal Architecture. The most notable marvels of Mughal Architecture are The Red Fort at Agra (1565-74), walled city of Fatehpur Sikri (156974) and the Taj Mahal, built by Shah Jahan (1628-58). Shah Jahan employed the double dome, the recessed archway, white marble and parks while stressing on symmetry and detail. The architecture during the Mughal Period, with its rulers being of Turco-Mongol origin, has shown a very good blend of Indian style combined with the Islamic and Persian styles.

\subsection{Influence of European Invasions}

\subsubsection{British influence}

The British overthrew the Mughal Empire in 1615 and reined over India for over 300 years. Today their legacy remains through building and infrastructure that developed their former colonies. The metropolitan cities colonized by them were Madras (Chennai), Calcutta (Kolkata), Bombay (Mumbai), Delhi, Agra, Bankipore, Karachi, Nagpur, Bhopal and Hyderabad.In Chennai the St Andrews Kirk is famous for its colonial planning. It has a circular plan and form and is sided by two rectangular sections one is the entrance porch which is lined with twelve colonnades and two British lions and motto of East India Company engraved on them. The interior has sixteen columns and the dome is blue and decorated with gold stars. 
The original Indian villages consisted of clay and straw houses. However after the British Raj the villages were transformed into a metropolis of brick and stone. The Victoria Memorial in Kolkata is the most powerful symbolism of British Empire. It was built as a tribute to Queen Victoria's reign. The plan consists of a large central dome over a large rotunda covered with a larger dome. 2 internal chambers are separated by colonnades. Each corner is topped with a smaller dome and the plinth is covered with marble floor. The monumental structure has gardens of 26 acres in area $\mathrm{d}$ surrounded by reflective pools.

\subsubsection{French Influence}

The French took reigned in parts of India from 1673 to 1954. They made Puducherry (Pondicherry) in Tamil Nadu their colony along with Chandan Nagar in West Bengal. However Puducherry exhibits the strongest influence of the French in their architecture, Planning and even culture. The fishing town of Puducherry was planned as per the French city planning pattern of grids with perpendicular streets dividing the town into 2 sections - the French Quarter or the White town (Ville Blanche) and the Indian Sector (Ville Noire). The houses were designed on the lines of the French villas integrating all the elements of a classic French villa. An organization called INTACH was formed to conserve the cultures and preserve the classic French architecture and essence of original Puducherry.

\subsubsection{Dutch Influence}

In $17^{\text {th }}$ century, India saw the trading interest of the Dutch. Hey entered India and colonized Surat, Ahmedabad, Malabar Coast, Bharuch, Sadras and Venrula for 200 years. They left their mark in each colony of theirs. In 1630's Dutch built a factory in Surat, a trading post of Dutch East India Company with a Dutch cemetery in Bharuch, a warehouse for 3000 in Venrula and Ahmedabad had a castle for protecting Dutch planned and built. The famous Dutch palace or the Mattancherry palace was built in Malabar Coast Kochi which was originally built by the Portuguese but came under control of the Dutch when Dutch took over Kochi.

\subsubsection{Portuguese Influence}

The Portuguese supremacy is maximum and evident in Goa. The Portuguese built superlative cathedrals, churches, basilicas and seminaries. One such example is that of the Basilica of Bom Jesus (Good Jesus) in Old Goa. It is a three storied Renaissance styled church that was designed and built of plaster and laterite in 1605, and holds the mortal remains of St. Francis Xavier.

The Portuguese influence and inspiration is evident even today in the Portuguese - Catholic houses that face the street with unique large ornamental windows opening out to verandas. Portuguese architecture in Goa used vernacular techniques of using mud or laterite stone for walls and vegetable dyes and natural dyes for paint.

\subsection{Indian Vernacular Planning}

Indian vernacular planning is world famous for using methods and techniques that assimilate all traditional architectural methods, Vastu Shastra, use of locally available materials and ancient town planning techniques like the technique of Mandalas for city planning which was used for planning the Indian city of Jaipur and to create sustainable, environment friendly, economic and aesthetically beautiful modern structures and towns. 


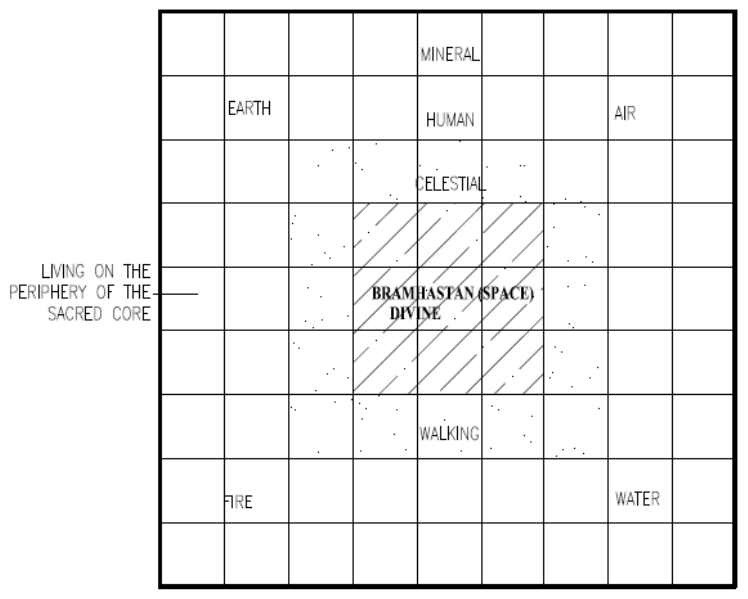

Figure 5: Grid planning according to Mandala

Timber was and is available in plenty in the valleys of river Indus and Ganges. White marble is a specialty of Rajasthan and used extensively in Jain temples and Mughal buildings during the reign of Shah Jahan. The vernacular structures due to their materials and planning are often earthquake resistant. The modern Indian built environment has undergone a lot of challenges and changes since globalization. However, it is of utmost importance to recognize and identify the main features that will enhance seismic performance of traditional buildings. There are some very general strategies for seismic feat of vernacular planning. India is the only country which still actively uses its traditional and ancient architectural and construction practices in modern times.

\section{Conclusions}

The world is evolving, times are changing and so are the likes, wants, desires and views of everybody in it. It is important to keep up with the tides of time. However to keep up with the modern times, there is no sense means letting go of our "history" or the roots of Built Environment. Conservation of the forgotten era (historic architecture and planning) not only keeps our traditions alive but also contributes to the economy and environment. The historic planning techniques are time tested and more effective if not more than the modern planning and construction techniques. Ancient Indian Architecture and planning taught the world the importance of vernacular architecture and planning to be incorporated in modern day planning. The classic architecture styles of different parts of the world depict their rich and vibrant culture and traditions. It is important to adopt the classic styles of architecture for future as it will not only glorify India's and the various parts of the world's rich culture and traditions but also contribute to the environment around us. Architecture flourishes when we combine classical style of architecture with contemporary styles.

\section{ACKNOWLEDGEMENTS}

I want to thank every individual who assisted me, directly or indirectly in this paper. 
Civil Engineering and Urban Planning: An International Journal(CiVEJ) Vol.3,No.1, March 2016

\section{REFERENCES}

[1] THE GREAT AGES OF WORLD ARCHITECTURE; AUTHOR- G.K.HIRASKAR

[2] SIR BANNISTER FLETCHER

[3] VEDIC PRINCIPLES OF PLANNING OF TEMPLE CITIES IN INDIA BY AR. IRAM AZIZ

[4] FOEKEMA, GERARD (1996), A COMPLETE GUIDE TO HOYSA!̣ TEMPLES, ABHINAV PUBLICATIONS

[5] JAFFAR, S.M (1936). THE MUGHAL EMPIRE FROM BABAR TO AURANGZEB. PESHAWAR CITY: MUHAMMAD SADIQ KHAN

[6] GAST, KLAUS-PETER (2007), MODERN TRADITIONS: CONTEMPORARY ARCHITECTURE IN INDIA, BIRKHÄUSER

[7] MOFFETT, MARION; FAZIO, MICHAEL W.; WODEHOUSE LAWRENCE (2003), A WORLD HISTORY OF ARCHITECTURE, MCGRAW-HILL PROFESSIONAL

[8] THAPAR, BINDIA (2004) INTRODUCTION TO INDIAN ARCHITECTURE. SINGAPORE: PERIPLUS EDITIONS

[9] TERESI, DICK (2002), LOST DISCOVERIES: THE ANCIENT ROOTS OF MODERN SCIENCE-FROM THE BABYLONIANS TO THE MAYA, SIMON \& SCHUSTER

[10] SINOPOLI, CARLA M. (2003), "ECHOES OF EMPIRE: VIJAYANAGARA AND HISTORICAL MEMORY,VIJAYANAGAR AS HISTORICAL MEMORY", ARCHAEOLOGIES OF MEMORY EDITED BY RUTH M. VAN DYKE \& SUSAN E. ALCOCK, BLACKWELL PUBLISHING

[11] NILSSON, STEN (1968). EUROPEAN ARCHITECTURE IN INDIA 1750 - 1850. LONDON: FABER AND FABER

\section{AUTHOR}

The author is an Indian Architect who is currently pursuing MBA in Real estate and urban Infrastructure from RICS SBE, Amity University. She is a professional painter with interest in History of architecture and conservation and urban planning.

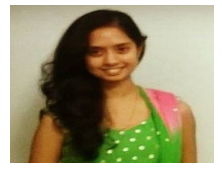

